\title{
Participatory ergonomics simulation of hospital work systems: The influence of simulation media on simulation outcome
}

\author{
Andersen, Simone Nyholm; Broberg, Ole
}

Published in:

Applied Ergonomics

Link to article, DOI:

10.1016/j.apergo.2015.06.003

Publication date:

2015

Document Version

Peer reviewed version

Link back to DTU Orbit

Citation (APA):

Andersen, S. N., \& Broberg, O. (2015). Participatory ergonomics simulation of hospital work systems: The influence of simulation media on simulation outcome. Applied Ergonomics, 51, 331-342.

https://doi.org/10.1016/i.apergo.2015.06.003

\section{General rights}

Copyright and moral rights for the publications made accessible in the public portal are retained by the authors and/or other copyright owners and it is a condition of accessing publications that users recognise and abide by the legal requirements associated with these rights.

- Users may download and print one copy of any publication from the public portal for the purpose of private study or research.

- You may not further distribute the material or use it for any profit-making activity or commercial gain

- You may freely distribute the URL identifying the publication in the public portal

If you believe that this document breaches copyright please contact us providing details, and we will remove access to the work immediately and investigate your claim. 


\section{Title page}

Title: Participatory ergonomics simulation of hospital work systems: The influence of simulation media on simulation outcome

First author/corresponding author: Andersen, Simone Nyholma, siman@dtu.dk, +45 30299154

Second author: Broberg, Ole a, obro@dtu.dk, +45 45256033

Affiliation: ${ }_{a}$ Technical University of Denmark, Department of Management Engineering, Produktionstorvet building 424, 2800 Kgs. Lyngby, Denmark. 


\title{
Participatory ergonomics simulation of hospital work systems: The influence of simulation media on simulation outcome
}

\begin{abstract}
Current application of work system simulation in participatory ergonomics (PE) design includes a variety of different simulation media. However, the actual influence of the media attributes on the simulation outcome has received less attention. This study investigates two simulation media: full-scale mock-ups and table-top models. The aim is to compare, how the media attributes of fidelity and affordance influence the ergonomics identification and evaluation in PE design of hospital work systems. The results illustrate, how the full-scale mock-ups' high fidelity of room layout and affordance of tool operation supports ergonomics identification and evaluation related to the work system entities space and technologies \& tools. The table-top models' high fidelity of function relations and affordance of a helicopter view supports ergonomics identification and evaluation related to the entity organization. Furthermore, the study addresses the form of the identified and evaluated conditions, being ether identified challenges or tangible design criteria.
\end{abstract}

Keywords: Participatory Simulation, Hospital Work Systems, Participatory Ergonomics. 


\section{Introduction}

A recognized problem in work system design is the occurrence of ergonomics problems after implementation of system changes, resulting in resource demanding and cost full readjustments to comply with the problems (Hendrick 2008). One way of preventing the ergonomics problems already during the design process is to include the future workers in participatory ergonomics (PE) (Wilson et al., 2005). PE has been defined as "the involvement of people in planning and controlling a significant amount of their own work activities, with sufficient knowledge and power to influence both processes and outcomes in order to achieve desirable goals” (Wilson, 1995).

Participatory simulation is a PE method that involves the future workers in design of work systems. A work system can be defined as “... a system in which human participants and/or machines perform work using information, technology, and other resources to produce products and/or services for internal or external customers" (Alter, 2006). Simulation has been defined as 'an imitation of the operation of a real-world process or system over time’ (Banks et al., 2010), and may have two purposes. The first being a method for identifying and evaluating the future work practices and ergonomics conditions (Daniellou, 2007; Daniellou et al., 2014; Nelson et al., 2013) and the second being a social process mediating mutual learning between workers and designers (Béguin, 2014). This study will concentrate on the first purpose.

A key component in participatory simulation is the simulation media (Daniellou, 2007), which represent the work system to be designed. Within the PE field, a variety of different simulation media are applied, all with the purpose of identifying or assessing ergonomics conditions and problems of the work system to be designed. Physical simulation media such as mock-ups and prototypes are applied for assessing work posture (Sundin et al., 2004), muscular discomfort (Paquet and Lin, 2003), physical layout and spatial conditions (Broberg et al., 2011; Steinfeld, 2004; Watkins et al., 2008). Computer based simulation media such as 3D computer animation and mixed reality have been applied for assessing muscular fatigue (Hallbeck et al., 2010; Perez et al., 2014), repetitive work and critical work sequences (Sundin and Medbo, 2003; Sundin et al., 2004).

The variation in ergonomics conditions indicates that different media support identification and assessment of different ergonomics conditions, which is a common reflection point in the literature (Hallbeck et al., 2010; Paquet and Lin, 2003; Steinfeld, 2004; Sundin and Medbo, 2003; Watkins et al., 2008). In addition, some studies indicate that the media have certain attributes, but these are not reflected upon in relation to the ergonomics conditions or problems actually possible to identify by applying the media. The media attributes indicated are the ability of the media to represent the reality (Hallbeck et al., 2010; Steinfeld, 2004; Watkins et al., 2008) and the possible actions the media support (Broberg et al., 2011; Steinfeld, 2004). Within the interaction design field, these attributes are recognized as fidelity (Hall, 2001; Lim et al., 2008) and affordance (Norman, 2002; Turner, 2005). Fidelity may be defined as "the level of detail or sophistication of what is manifested" (Lim et al., 2008). Affordance may be defined as "the perceived and actual properties of the thing... that determine just how the thing could possibly be used" (Norman, 2002). How these two media attributes influence the outcome of simulations, in the form of identified ergonomics conditions, has received little attention in the participatory simulation field.

The Danish healthcare sector is currently a relevant empirical setting for exploring the influence of the simulation media attributes. At the moment, the sector is in a comprehensive design process for new public hospitals, which includes an extensive application of participatory simulation, involving healthcare professionals in PE design. The design activities may be conceptualized as a matter of designing hospital 
work systems. This study is based on two case studies of participatory simulation events, applying two different simulation media: full-scale mock-ups and table-top models. The aim is to compare, how the fidelity and affordance attributes of these two types of simulation media may influence the ability to identify and evaluate ergonomics conditions during PE design of hospital work systems.

Our basic assumption was that the two simulation media would have different capabilities in supporting identification and evaluation of ergonomics conditions because of difference in the attributes. By adapting the International Ergonomics Association's definition, ergonomics conditions are defined as: (1) conditions influencing the healthcare professionals' well-being in the future work system, e.g. work posture, psychosocial work load, indoor climate, safety and division of labor; and (2) conditions influencing the work system's overall performance, e.g. efficiency, consumption of resources, quality of system output and risk of errors. We refer to identification as the process of simulation participants being able to articulate or visually show possible ergonomics challenges of the future work system. We refer to evaluation as the process of participants being able to formulate tangible design criteria based on discussions of the identified ergonomics conditions.

In the following, we first define the key work system concept, followed by the methodological approach, including the introduction of the two cases. We present the results from the analysis in the form of the identified and evaluated ergonomics conditions of the two cases and the influence of fidelity and affordance. In the discussion, the results of each case are compared and related to existing studies on full-scale mock-ups and table-top based models. We end with concluding remarks, including implications for practitioners.

\section{The work system concept}

In order to analyze the participatory simulation phenomenon, we introduce the work system concept. A work system have been defined as consisting of different interconnected entities (Alter, 2006; Carayon, 2009; Horgen et al., 1999; Kleiner, 2006). We operate with six entities: work practice, participants, information, tools \& technologies, space and organization. The work practice is the work activities within the work system (Alter, 2006). The participants are the people who perform the work (Alter, 2006) and have psychosocial, cognitive and physical characteristics (Carayon, 2009). The information is explicit and tacit knowledge, which is exchanged as participants perform their work (Alter, 2006). The technologies \& tools are the tools that helps participants work efficiently (Alter, 2006; Carayon, 2009). The space is the physical environment and workspace design (Carayon, 2009; Horgen et al., 1999). The organization is the organizational design, the organization of work, coordination of work (Kleiner, 2006), work scheduling and culture (Carayon, 2009). The six entities of the work system concept are applied as an analytical frame to help identify, to what extent the entities are addressed in the two simulation cases.

\section{Methodology}

The Danish healthcare sector is designing and building new public hospitals, with the purpose of increasing the quality and efficiency of the healthcare service. The design process includes redesign of the current hospital work systems. To facilitate user participation in the work systems design, the Danish Regional Councils have established innovation centers spread around the country. A significant part of the centers' activities are based on participatory simulation, involving healthcare professionals from the existing hospitals. We had the opportunity to study participatory simulation in two innovation centers, each related to a hospital design project. The first center applied full-scale mock-ups as simulation media, and the second center applied table-top models as simulation media. We considered the simulation activities of the centers as naturally occurring data, described as "real interactions happening naturally out in the world" (Potter, 
2004), contrasting controlled laboratory experiments. These naturally occurring simulation activities provided a unique opportunity for studying, how the fidelity and affordance of these two types of simulation media may influence the ability to identify and evaluate ergonomics conditions. We approached the simulation activities of the two hospital design projects as two case studies, each constituting of four simulation events viewed as nested units of analysis (Thomas, 2011). The simulation activities in both cases had the purpose of providing input to the engineers and architects, who designed the new hospital buildings during complex design processes. However, in this study we focus exclusively on the actual ergonomics outcomes of the simulations. The two cases are described in the following sections 3.1 and 3.2.

\subsection{Full-scale mock-ups}

The innovation center of the first case study was part of the building process of a new hospital, which replaced two current hospitals. The center was located in a hall at the construction site, containing mock-ups facilities. The facilities were managed by two center employees: one with a clinical background and one with an occupational health and safety background. The purpose of the center was to test standard room proposals for the somatic hospital and thereby contribute to the architectural design process.

The four simulation events, constituting the case as presented in Table 1, were based on blueprints of room proposals provided by the consulting architects. The room proposals were key rooms in the sense that the rooms would be extensively repeated throughout the hospital. The proposals were transformed into full-scale mock-ups based on movable chipboard walls, big foam bricks and standard hospital interior, see Figure 1. The mock-ups were constructed by the two center employees prior to the simulation events.

\section{(Insert Table 1)}

Table 1: Key characteristics of the four simulation events of the first case study. (Two column table)

\section{(Insert Figure 1)}

Figure 1: Full-scale mock-ups applied in the first case. (One column figure)

The participants of the four simulation events were healthcare professionals with various professions; project employees from the project owner organization; engineers and architects from the consulting companies; and the two center employees. The center employees selected the participating healthcare professionals on the criteria of having work experience in the room to be tested.

Each of the four simulation events constituted of two parts. The first part was an introduction meeting, where the center employees introduced the simulation participants to the architect's room proposal. The introduction led to discussions of possible challenges of the room, e.g. problems about work postures or work practices. Using the identified challenges as a starting point, the participants developed scenarios based on possible future work practices, e.g. handling of a wheelchair in an examination room. The second part comprised the simulation in which the healthcare professionals initiated work processes in the mock-ups. The simulation was facilitated by the center employees in an open manner, in the sense that the direction of the simulation was highly influenced by the participants continually developing the simulation scenarios further. The continual scenario development resulted in a mixture of; experimental simulation, where the participants enacted scenarios in the mock-ups, e.g. pushed a bed around the cornered corridor; and narrative simulation, where the participants discussed scenarios while standing in the mock-ups, e.g. how coordinating technology could support the work of the nurses. 


\subsection{Table-top models}

The simulation events of the second case study were a part of a healthcare innovation project managed by the regional innovation center. The project aimed at contributing to the designing of a new outpatient department building for an existing hospital. Furthermore, the project was a research project for testing simulation methods in healthcare innovation. The vision for the project was to involve healthcare professionals from the exiting outpatient department, consultants from industry, simulation consultants from the Danish Institute of Medical Simulation and researchers.

The four simulation events of the case are presented in Table 2. The simulation media were in table-top size, consisting of an A0-poster, where LEGO figures and cardboard boxes were arranged, see Figure 2. The LEGO figures depicted patients and healthcare professionals. The cardboard boxes illustrated rooms, and the configuration of the boxes illustrated conceptual building layouts. With a foundation of comprehensive research in the work practices of the current outpatient department, the layout proposals were developed by the participating healthcare professionals before each simulation event.

(Insert Table 2)

Table 2: Key characteristics of the four simulation events of the second case study. (Two column table)

\section{(Insert Figure 2)}

Figure 2: Table-top models applied in the second case. (One column figure)

The participants of the four simulation events were healthcare professionals from the existing outpatient department, simulation consultants, consultants from industry and researchers. However, the healthcare professionals had the most active simulation role, whereas the researchers and consultants from industry observed and occasionally participated, when multiple patient treatments were simulated. Furthermore, one of the simulation consultants acted as the main game-master. The participating healthcare professionals were selected by management of the outpatient department based on the criteria including representatives from the three main employee groups: physicians, nurses and secretaries.

Each of the four simulation events constituted of two parts. The first part was the actual simulation event based on simulation scenarios, previous developed by the simulation consultants and department management. The scenarios were based on comprehensive research of the work practices at the department and illustrated patient trajectories from the existing outpatient department. The scenarios included a list of tasks with assigned simulation time as a third of real time. In combination with the predefined scenarios, each simulation event was aiming at investigating a simulation question, e.g. "what if we introduced two physicians per three examination rooms?”

For the simulation, each of the participants was assigned a scenario role reflecting their professional background, a LEGO figure and a colored marker pen. The participants, who were assigned the role as patients, were supplied with an egg-timer for managing the simulation time of the scenarios. The participants moved the LEGO figures around the table-top model according to the scenario while simultaneously drawing the movements on the A0 poster. During the simulation, the game-master introduced predefined disturbances, e.g. the need for experienced physicians supervising less experienced physicians. The disturbances challenged the participants to develop creative solutions within the frame of the scenarios. The second part of the simulation event was an extensive debriefing managed by the game-master and the 
researchers. In the debriefing, the participants were able to discuss the insights obtained from the previous simulations.

\subsection{Case selection}

Our initial assumption for this study was that different simulation media have different capabilities in supporting identification and evaluation of ergonomics conditions due to variation in media attributes. The two cases provided a unique opportunity for studying this assumption, which until now has received minimal attention in the human factors and ergonomics field. Furthermore, the two cases complied with the case selection criterion on maximum variation (Flyvbjerg, 2006) by applying two 'opposite' simulation media in terms of fidelity and affordance. The variation in fidelity and affordance is elaborated in Table 3 . The purpose was to search for both differences and commonalities. Differences in relation to our assumption of different capabilities of the media. Commonalities in relation to a common pattern in how media attributes connect to these capabilities. Identification of commonalities is argued to be strengthened when the cases vary in maximum degree (Neergaard, 2010).

(Insert Table 3)

Table 3: The fidelity and affordance of the two simulation media. (Two column table)

\subsection{Data collection and analysis}

The data analysis was based on video-recordings of the simulation events. The video-recordings were executed with a fixed camera with the purpose of getting a wide view of the simulation activities, and thereby capture as much interaction and visual conduct of the participants as possible (Heath et al., 2010). The authors had different roles in relation to the data collection and analysis. The first author recorded and observed the simulation events of the first case. The second author recorded and participated as one of the researchers in the second case, applying an action research perspective. In both cases, the simulation events were not conducted with a research purpose of media attributes in mind, the overall purpose was to contribute to hospital work system design. Thereby, the comparative potential of the cases was recognized afterwards. Aiming at conducting a comparative analysis, the first author analyzed the video-recordings of both cases from the perspective of being an observer of the recorded events. During the analysis the second author acted as discussion partner.

The first author's observations of the 'live' simulations of the first case and the second author's participation in the simulations of the second case provided insights into the activities taking place before and after recording periods. These insights were important for understanding reasons behind discussions and actions of the simulation participants as captured in the recordings. Furthermore, the observations of the first case gave the opportunity for viewing actions, which were not explicit to the camera because e.g. people occasionally stood behind walls in the full-scale mock-ups. In these cases, the observations were necessary to fill in these particular sequences in the video-recording.

The video-recordings of each case were analyzed in two phases. The first phase investigated the types of ergonomics conditions identified in both cases from a quantitative perspective. The second phase investigated the evaluation possibility of the identified conditions and the relation to the media attributes from a qualitative perspective. The two phases of analysis were intended to supplement each other by providing both a quantitative and qualitative view on the two case studies as a triangulation strategy (Silverman, 1993). The two phases are illustrated in Figure 3 and elaborated in the following paragraphs. 
(Insert Figure 3)

Figure 3: The first and second step of analysis. (Two column figure)

The first phase of analysis was a content analysis (Berg, 2001) of the video-recordings. The analysis was based on coding for identifying video-sequences where simulation participants identified ergonomics conditions, and ordering these according to the six work system entities, step 1 and 2 in Figure 3 . The first author coded the videos for sequences where participants identified ergonomics conditions. By identify, we mean simulation participants articulated or visually showed ergonomics conditions, e.g. by discussing or acting out possible future ergonomics challenges. By ergonomics conditions, we mean conditions that influence the well-being of the future healthcare professionals or the performance of the future work system. The identified sequences were transcribed as a combination of voice and visual conduct (Heath et al., 2010). We ordered the sequences according to which of the six work system entities the identified conditions related to. Some sequences were related to several entities and were thereby represented more than once, whereas other sequences only related to one entity. The total number of transcribed sequences, including duplicates, was 259 of the first case and 323 of the second case. The number of sequences per work system entity was normalized according to the total number of sequences per case.

The second phase of analysis was an inductive approached searching for patterns (Thomas, 2006) within the transcribed sequences of each work system entity, step 3 in Figure 3. This resulted in identification of several subgroups of identified conditions within each work system entity. We assessed these subgroups on two levels: the evaluation possibility and the influence of media attributes, step 4 and 5 in Figure 3. The evaluation possibility was assessed to find out whether the subgroups were purely identified ergonomics conditions or actually possible to evaluate. The following question guided the assessment: what is the possibility for the simulation participants to formulate a tangible design criterion from discussions of the identified ergonomics conditions? A tangible design criterion is a statement that a work system designer can directly apply, e.g. "this wall must be moved one meter as minimum, in order to have a proper work posture.” A less tangible design criterion is a statement of a challenge to take into consideration during work system designing, e.g. "there must be sufficient natural light inflow for the work taking place." The influence of media attributes was assessed from the guiding question: how are the media attributes of fidelity and affordance influencing by ether supporting or opposing the evaluation process?

\section{Results}

In this section, we present the results of the analysis: the ergonomic conditions identified and the evaluation possibility of the subgroups of identified conditions. The quantification of identified ergonomics conditions is presented in Figure 4. The figure shows the distribution of video-sequences, where the participants identified conditions related to one or more of the six work system entities. The first case study of the fullscale mock-ups had a high percentage of identified ergonomics conditions related to space and technologies $\&$ tools. The second case study of the table-top models had a high percentage of identified ergonomics conditions related to organization. The exact distribution percentages of identified ergonomics conditions are presented in Appendix 1.

(Insert Figure 4)

Figure 4: The distribution per case study of the amount of video-sequences where the simulation participants identified ergonomics conditions in relation to the entities of the six work system entities. (Two column figure) 
During the second step of analysis we realized that the simulation participants were not able to evaluate all the subgroups of identified conditions. This difference in evaluation possibility was especially interesting for the identified conditions related to space and technologies \& tools in the first case, and organization in the second case. We expected that the media's high capabilities in supporting identification of conditions related to these work system entities would additionally lead to high evaluation possibilities of these conditions. However, assessment of the subgroups revealed that not all identified conditions were able to be evaluated by the simulation participants. The fidelity level and affordance showed influence on the evaluation possibility.

In the situations where the participants were able to evaluate conditions, the fidelity relating to that condition showed to be high. Furthermore, affordance of actions relating to the condition under evaluation also showed to support the evaluation possibility. In the situations where the participants had difficulties in evaluating a condition, the media attributes showed not to influence the discussion. These discussions were triggered by the simulation media, but became detached from the media along the way, in the sense that the participants could not actively apply the media in their argumentation. Thereby, the participants did not reach a common agreement. The evaluation possibility and the influence of media attributes are presented in Table 4. For an overview of the evaluation possibility for subgroups of all six work system entities see Appendix 1.

\section{(Insert Table 4)}

Table 4: The evaluation possibility of the subgroups of the three dominating work system entities, and the influence of the media attributes. (Two column table)

\section{Discussion}

The results of the first step of analysis showed differences between the full-scale mock-ups and the table-top models in relation to the number of identified ergonomics conditions related to the six work system entities. The differences indicate that the two types of simulation media and their in attributes support different ergonomics identification of the future hospital work systems. Furthermore, the media attributes additionally showed an influence on the evaluation possibility of the identified conditions, leading to the discovery that not all the subgroups of the work system entities could be evaluated. Considerations on the influence of media attributes are discussed in the following sections together with considerations on influencing contextual factors.

\subsection{Influence of media attributes on identification}

The two simulation cases represented 'opposite' media in terms of media attributes. The full-scale mock-ups had a high fidelity level in regards to room dimensions, room layout, tool positions and tool dimensions. Furthermore, the full-scale mock-ups afforded configuration of the movable walls and operation of tools. These attributes connected to the high amount of identified ergonomics conditions related to the entities technologies \& tools and space. In contrast, the table-top models showed low fidelity of the room dimensions and room layout, because the rooms were 'black-boxed' into cardboard boxes. However, the table-top models had a high fidelity of the overall organization and building layout of the future work system. Furthermore, the table-top models afforded room configurations and a helicopter view. These attributes connected to the high amount of identified ergonomics conditions related to the work system entity organization. 
In existing studies applying full-scale mock-ups in PE activities and hospital design, the ergonomics conditions identified are also related to the entities technologies \& tools and space. Existing studies applying table-top based simulation in production and building planning also identify conditions related to organization. The identified conditions are presented in Table 5 . The purpose of Table 5 is not to identify all published studies of full-scale mock-ups and table-top based models, but to identify studies representing the application variety of theses simulation media in participatory design activities.

In some of the existing studies, the authors reflect upon the simulation media fidelity in the form of detail level (Watkins et al., 2008) or the situation being 'too finished' (Bligård et al., 2014). Some studies actually refer to the concept of fidelity as influencing discussions among participants (Persson et al., 2014), being important in different design phases (Watkins et al., 2008) and being 'good enough' (Hallbeck et al., 2010). However, the connection between the fidelity and the actual identified ergonomics conditions has not been analyzed or defined.

The existing studies acknowledge in some ways that simulation media have different affordances. The fullscale mock-ups are referred to as giving a bodily experience (Bligård et al., 2014; Persson et al., 2014) and being flexible to use (Paquet and Lin, 2003; Peavey et al., 2012; Villeneuve et al., 2007). The table-top based models are discussed as providing an overview (Bligård et al., 2014; Ruohomäki, 2003; Savolainen, 1997). However, these properties are not defined as affordance, nor are they analyzed in relation to the conditions actually identified. Our study contributes to the existing studies by actually analyzing the connection between the identified ergonomics conditions and the media fidelity and affordance. We argue for the importance of considering this connection, when planning participatory simulation with the purpose of contributing to work system design by identifying ergonomics conditions.

\section{(Insert Table 5)}

Table 5: Identified ergonomics conditions of existing studies of full-scale mock-ups and table-top based simulation. (Two column table)

\subsection{Influence of media attributes on evaluation}

In this study, we distinguish between identification and evaluation of ergonomics conditions. We define conditions with high evaluation possibility as fostering development of tangible design criteria, ready to be applied by work system designers. Whereas conditions with low possibility for evaluation have the characteristics of being less tangible and having the form of challenges to take into consideration during design. Existing studies on full-scale mock-ups and table-top based models show little consideration in regards to the form of the simulation outcomes, whether being directly applicable in design or challenges to take into account. Few studies define tangible design criteria (Hignett et al., 2010; Villeneuve et al., 2007; Watkins et al., 2008) and assess conditions (Daniellou et al., 2014; Hallbeck et al., 2010; Paquet and Lin, 2003; Ruohomäki, 2003). However, the development of these design criteria and assessment of the conditions are not analyzed in relation to the media fidelity and affordance.

During our analysis, we identified the fidelity of the full-scale mock-ups and table-top models as influencing the conditions possible to be identified. For example in the mock-ups, the ergonomics conditions, relating to the high fidelity areas of room dimensions and room layout, illustrated evaluation possibility. In contrast, the ergonomics conditions, relating to areas of the work system that the mock-ups manifested with a lower level of fidelity, were harder to evaluate. The mock-ups manifested e.g. the light and noise conditions of the hospital work systems to a low fidelity, because the mock-ups were situated in a hall, not reflecting the 
natural light and noise level. Thereby, the fidelity level manifested certain parts of the work system to a higher degree, seeming to support the evaluation of conditions related to these work system parts.

Furthermore, we identified the affordance of the full-scale mock-ups and table-top models as influencing the evaluation possibility. As an example, the table-top models' affordance of room configurations supported evaluation possibility of ergonomics conditions related to work organization and coordination between rooms and healthcare staff. However, ergonomics conditions related to e.g. external functions outside the simulated hospital department were harder to evaluate. This was possibly because the table-top models afforded configuration of rooms and functions defined to be situated within a specific department. In this way, the affordance related to certain parts of the work system demonstrated to support evaluation of these parts.

To increase the integration of the simulation outcome in the work system design, we argue for the importance of considering the form of the simulation outcome. In this manner, not simply aim at identifying ergonomics conditions, but actually evaluate these. The ergonomics conditions of interest may vary according to the stage of the work system design process. The fidelity level should be high in relation to the elements that are of evaluation interest, and the affordance should support overview or configuration of these elements.

\subsection{Influence of three contextual factors}

This study argues that simulation media attributes influence the capability of supporting identification and evaluation of ergonomics conditions. Nevertheless, three contextual factors might also influence the identification and evaluation. The first contextual factor was the scenarios. The scenarios in the two cases were narratives of possible future work challenges and questions related to the work system represented by the simulation media. However, the two cases introduced the scenarios in different ways. In the first case, scenarios were continually developed during the simulation events by the healthcare professionals. In the second case, scenarios included a time factor and were defined beforehand by the simulation consultant and department managers. Existing studies show that scenarios stimulate the ideation in design (Carroll, 2000; Suri and Marsh, 2000). Thereby, the difference in the introduction of scenarios in the two cases of this study might have resulted in different stimulation of ideation, influencing the ergonomics identification and evaluation.

The second contextual factor was the facilitation. Both the cases had facilitators directing the progress of the simulation events. However, the facilitation style was different in each case. The facilitation in the first case was 'open' in the sense that the participants led the simulation event in an exploratory manner. In the facilitation in the second case was regulated by the progress of the predefined scenarios and disturbances. Existing studies on facilitation in simulation as an education method show a high importance of the facilitation style in relation to the participants' educational profit (Clapper, 2014). Drawing on this research, the facilitation style may well be important for the profit of simulation as participatory ergonomics design method. Thereby, the difference in facilitation style of the two cases might have influenced the potential for ergonomics identification and evaluation.

The third contextual factor was the participants. The two cases included different participants in the sense of having different personal skills, backgrounds and experiences. Some of the participants were the future work system users, where other participants were designers of the future work system. Existing studies show the difficulty in choosing the 'best' participants in participatory processes (Reuzeau, 2001), indicating that 
different participants bring different perspectives to the process. In this way, the different participants of the simulation events might have brought different perspective on the ergonomics identification and evaluation.

\subsection{Methodological limitations of the study}

The study is based on two cases of naturally occurring (Potter, 2004) simulation events. This gave in-depth understanding into the influence of simulation media on ergonomics identification and evaluation of these eight events. This in-depth understanding is obtained within the boundaries of the two case studies, which in some degree limits the generalizability (Thomas, 2011). However, findings of common patterns between cases are argued to be strengthened when the cases vary in maximum degree (Flyvbjerg, 2006; Neergaard, 2010). Despite of the high variation between the type of conditions identified and evaluated, the comparative analysis actually showed a common pattern in how the fidelity and affordance influenced the identification and evaluation of ergonomics conditions. As verification, we have in addition compared the results of the two case studies with results of existing studies of full-scale mock-ups and table-top based models. The identified and evaluated conditions in the existing studies show to be consistent with our results. However, the connection between the media attributes and the conditions is not analyzed in the existing studies, as we aim for in this study. For further validation of this connection, we suggest research of other media such as virtual reality or small-scale mock-ups.

\section{Concluding remarks}

The aim of this study was to compare how the fidelity and affordance attributes of full-scale mock-ups and table-top models might influence the ability to identify and evaluate ergonomics conditions of future hospital work systems. This aim addressed the under-researched topic of the connection between simulation media attributes and the simulation outcome. Naturally occurring (Potter, 2004) simulation events in two Danish hospital building projects provided a unique opportunity for studying this connection from a case study perspective. The first case was based on full-scale mock-ups and the second case was based on table-top models.

Investigation of the two cases showed a difference between the identified and evaluated ergonomics conditions related to the future hospital work systems. The two types of media had a high level of fidelity in relation to different entities of the future work systems. Furthermore, the two media afforded actions in relation to different work system entities. In both cases, high fidelity and affordance of actions, relating to certain work system entities, appeared to support identification and evaluation of ergonomics conditions especially in relation to these entities. Existing studies of full-scale mock-ups and table-top based models showed identification of the same types of conditions. However, they did not analyze how media attributes influenced the identification. Neither did they address the importance of the form of the simulation outcome, in the sense of being identified challenges to taking into account when designing or being tangible design criteria developed from ergonomics evaluation. This study emphasized the importance of considering the form of the outcome, and how the media attributes influence the possibility of reaching that outcome.

\subsection{Implications for practitioners}

We suggest the following implications for practitioners:

- When choosing simulation media in the planning of participatory simulation activities, practitioners should consider the relation between the intended simulation outcome and the attributes of fidelity and affordance. 
- One media cannot support identification and evaluation of all types of ergonomics conditions. Thereby, the media attributes should target the areas of the work system, which are intended to be evaluated.

- The choice of simulation media should correspond with the present phase of the design process, where different phases require different ergonomics contribution. E.g. the concept design phase of buildings might require input about organization of functions, whereas the project phase might require input about detailed room layout.

\section{Acknowledgement}

We gratefully acknowledge the financial support of the Danish Working Environment Research Foundation, grant number 36-2012-09. 
Appendix A

(Insert Table A.1)

Table A.1: Results from the analysis of the two multiple case studies. (Two column table) 
References

Alter, S., 2006. Work systems - The source of business results, in: The Work System Model - Connecting People, Processes and IT for Business Results. Work system press, Larkspur, pp. 9-20.

Banks, J., Carson II, J.S., Nielson, B.L., Nicol, D.M., 2010. Introduction to simulation, in: Stark, H., Disanno, S. (Eds.), Discrete-Event System Simulation. Pearson Education, New Jersey, pp. 3-23.

Béguin, P., 2014. Learning during design through simulation, in: Broberg, O., Fallentin, N., Hasle, P., Jensen, P.L., Kabel, A., Larsen, M.E., Weller, T. (Eds.), 11th International Symposium on Human Factors in Organisational Design and Management \& 46th Annual Nordic Ergonomics Society Conference. IEA, Copenhagen, pp. 867872.

Berg, B.L., 2001. An Introduction to Content Analysis, in: Qualitative Research Methods for the Social Sciences. Allyn \& Bacon, pp. 238-267.

Bligård, L., Österman, C., Berlin, C., 2014. Using 2D and 3D models as tools during a workplace design process - a question of how and when, in: Broberg, O., Fallentin, N., Hasle, P., Jensen, P.L., Kabel, A., Larsen, M.E., Weller, T. (Eds.), 11th International Symposium on Human Factors in Organisational Design and Management \& 46th Annual Nordic Ergonomics Society Conference. IEA, Copenhagen, pp. 799-804.

Broberg, O., Andersen, V., Seim, R., 2011. Participatory ergonomics in design processes: the role of boundary objects. Appl. Ergon. 42, 464-472. doi:10.1016/j.apergo.2010.09.006

Carayon, P., 2009. The Balance Theory and the Work System Model ... Twenty Years Later. Int. J. Hum. Comput. Interact. 25, 313-327. doi:10.1080/10447310902864928

Carroll, J., 2000. Five reasons for scenario-based design. Interact. Comput., HICSS '99 13, 43-60.

Clapper, T.C., 2014. Situational Interest and Instructional Design: A Guide for Simulation Facilitators. Simul. Gaming 45, 167-182. doi:10.1177/1046878113518482

Daniellou, F., 2007. Simulating future work activity is not only a way of improving workstation design. @ctivités 4, 84-90.

Daniellou, F., Le Gal, S., Promé, M., 2014. Organisational simulation: anticipating the ability of an organisation to cope with daily operations and incidents, in: Broberg, O., Fallentin, N., Hasle, P., Jensen, P.L., Kabel, A., Larsen, M.E., Weller, T. (Eds.), 11th International Symposium on Human Factors in Organisational Design and Management \& 46th Annual Nordic Ergonomics Society Conference. IEA, Copenhagen, pp. 781-785.

Ewenstein, B., Whyte, J.K., 2007. Visual representations as “artefacts of knowing.” Build. Res. Inf. 35, 81-89. doi:10.1080/09613210600950377

Flyvbjerg, B., 2006. Five Misunderstandings About Case-Study Research. Qual. Inq. 12, 219-245. doi:10.1177/1077800405284363

Forssén-Nyberg, M., Makamäki, J., 1998. Development of the production using participative simulation games: Two case studies. int. J.Production Econ. 5273, 169-178.

Hall, R.R., 2001. Prototyping for usability of new technology. Int. J. Hum. Comput. Stud. 55, 485-501. doi:10.1006/ijhc.2001.0478

Hallbeck, M.S., Bosch, T., Rhijn, G.J.W. Van, Krause, F., Looze, M.P. De, Vink, P., 2010. A Tool for Early Workstation Design for Small and Medium Enterprises Evaluated in Five Cases. Hum. Factors Ergon. Manuf. Serv. Ind. 20, 300-315. doi:10.1002/hfm

Heath, C., Hindmarsh, J., Luff, P., 2010. Video in Qualitative Research. SAGE Publications Ltd, London.

Hendrick, H.W., 2008. Applying ergonomics to systems : Some documented "“lessons learned.”” Appl. Ergon. 39, 418426. doi:10.1016/j.apergo.2008.02.006

Hignett, S., Lu, J., Fray, M., 2010. Two Case Studies Using Mock-Ups for Planning Adult and Neonatal Intensive Care Facilities. J. Healthc. Eng. 1, 399-413. doi:10.1260/2040-2295.1.3.399

Horgen, T.H., Joroff, M.L., Porter, W.L., Schön, D.A., 1999. Excellence by Design: Transforming Workplace and Work Practice. John Wiley \& Sons, New York.

Kleiner, B.M., 2006. Macroergonomics: analysis and design of work systems. Appl. Ergon. 37, 81-89. doi:10.1016/j.apergo.2005.07.006

Lim, Y.-K., Stolterman, E., Tenenberg, J., 2008. The anatomy of prototypes. ACM Trans. Comput. Interact. 15, 1-27. doi:10.1145/1375761.1375762

Neergaard, H., 2010. Udvælgelse af cases i kvalitative undersøgelser, 3rd ed. Forlaget Samfundslitteratur.

Nelson, J., Buisine, S., Aoussat, A., 2013. Anticipating the use of future things: Towards a framework for prospective use analysis in innovation design projects. Appl. Ergon. 44, 948-956. doi:10.1016/j.apergo.2013.01.002

Norman, D.A., 2002. The Design of Everyday Things. Basic Books.

Paquet, V., Lin, L., 2003. An integrated methodology for manufacturing systems design using manual and computer simulation. Hum. Factors Ergon. Manuf. 13, 19-40. doi:10.1002/hfm.10026

Peavey, E.K., C, L.A.P.B.D., Aia, A., 2012. Simulation and Mock-Up Research Methods To Enhance Design Decision Making. Heal. Environ. Res. Des. J. 5, 133-144. 
Perez, J., de Looze, M.P., Bosch, T., Neumann, W.P., 2014. Discrete event simulation as an ergonomic tool to predict workload exposures during systems design. Int. J. Ind. Ergon. 44, 298-306. doi:10.1016/j.ergon.2013.04.007

Persson, J., Hornyánszky Dalholm, E., Johansson, G., 2014. Informing Hospital Change Processes Through Visualization and Simulation: A Case Study at a Children's Emergency Clinic. Heal. Environ. Res. Des. J. 8, 4566.

Potter, J., 2004. Discourse Analysis as a Way of Analysing Naturally Occuring Talk, in: Silverman, D. (Ed.), Qualitative Research: Theory, Method and Practice. SAGE Publications, London, pp. 200-221.

Reuzeau, F., 2001. Finding the best users to involve in design: A rational approach. Trav. Hum. 64, $223-245$.

Riis, J.O., 1996. Games for implementing changes in industrial enterprises, in: Saunders, D., Percival, F., Vartiainen, M. (Eds.), The Simulation and Gaming Yearbook Volume 4. Games and Simulations to Enhance Quality Learning. Jessica Kingsley Publishers, pp. 72-84.

Ruohomäki, V., 2003. Simulation Gaming for Organizational Development. Simul. Gaming 34, 531-549. doi:10.1177/1046878103258203

Savolainen, T., 1997. Simulation games in CIM and the learning organisation. Comput. Ind. 33, $217-221$.

Silverman, D., 1993. Validity and Reliability, in: Interpreting Qualitative Data. SAGE Publications Ltd, London, pp. 144-170.

Steinfeld, E., 2004. Modeling spatial interaction through full-scale modeling. Int. J. Ind. Ergon. 33, $265-278$. doi:10.1016/j.ergon.2003.06.004

Sundin, A., Christmansson, M., Larsson, M., 2004. A different perspective in participatory ergonomics in product development improves assembly work in the automotive industry. Int. J. Ind. Ergon. 33, 1-14. doi:10.1016/j.ergon.2003.06.001

Sundin, A., Medbo, L., 2003. Computer visualization and participatory ergonomics as methods in workplace design. Hum. Factors Ergon. Manuf. 13, 1-17. doi:10.1002/hfm.10025

Suri, J.F., Marsh, M., 2000. Scenario building as an ergonomics method in consumer product design. Appl. Ergon. 31, $151-157$.

Thomas, D.R., 2006. A General Inductive Approach for Analyzing Qualitative Evaluation Data. Am. J. Eval. 27, 237246.

Thomas, G., 2011. How to do your case study - A guide for students and researchers. SAGE Publications, London.

Turner, P., 2005. Affordance as context. Interact. Comput. 17, 787-800. doi:10.1016/j.intcom.2005.04.003

Villeneuve, J., Lu, J., Hignett, S., Duffy, A.E., 2007. Ergonomic Intervention in Hospital Architecture, in: Pikaar, R., Koningsveld, E., Settels, P. (Eds.), Meeting Diversity in Ergonomics. Elsevier, pp. 243-269.

Watkins, N., Myers, D., Villasante, R., 2008. Mock-Ups as “Interactive Laboratories”: Mixed Methods Research Using Inpatient Unit Room Mock-Ups. Heal. Environ. Res. Des. J. 2, 66-81.

Wilson, J., 1995. Ergonomics and participation, in: Wilson, J.R., Corlett, E.N. (Eds.), Evaluation of Human Work: A Practical Ergonomics Methodology. Taylor \& Francis Ltd., London, pp. 1071-1096.

Wilson, J., Haines, H., Morris, W., 2005. Participatory ergonomics, in: Wilson, J.R.., Corlett, N. (Eds.), Evaluation of Human Work. Taylor \& Francis Group, pp. 932-962. 

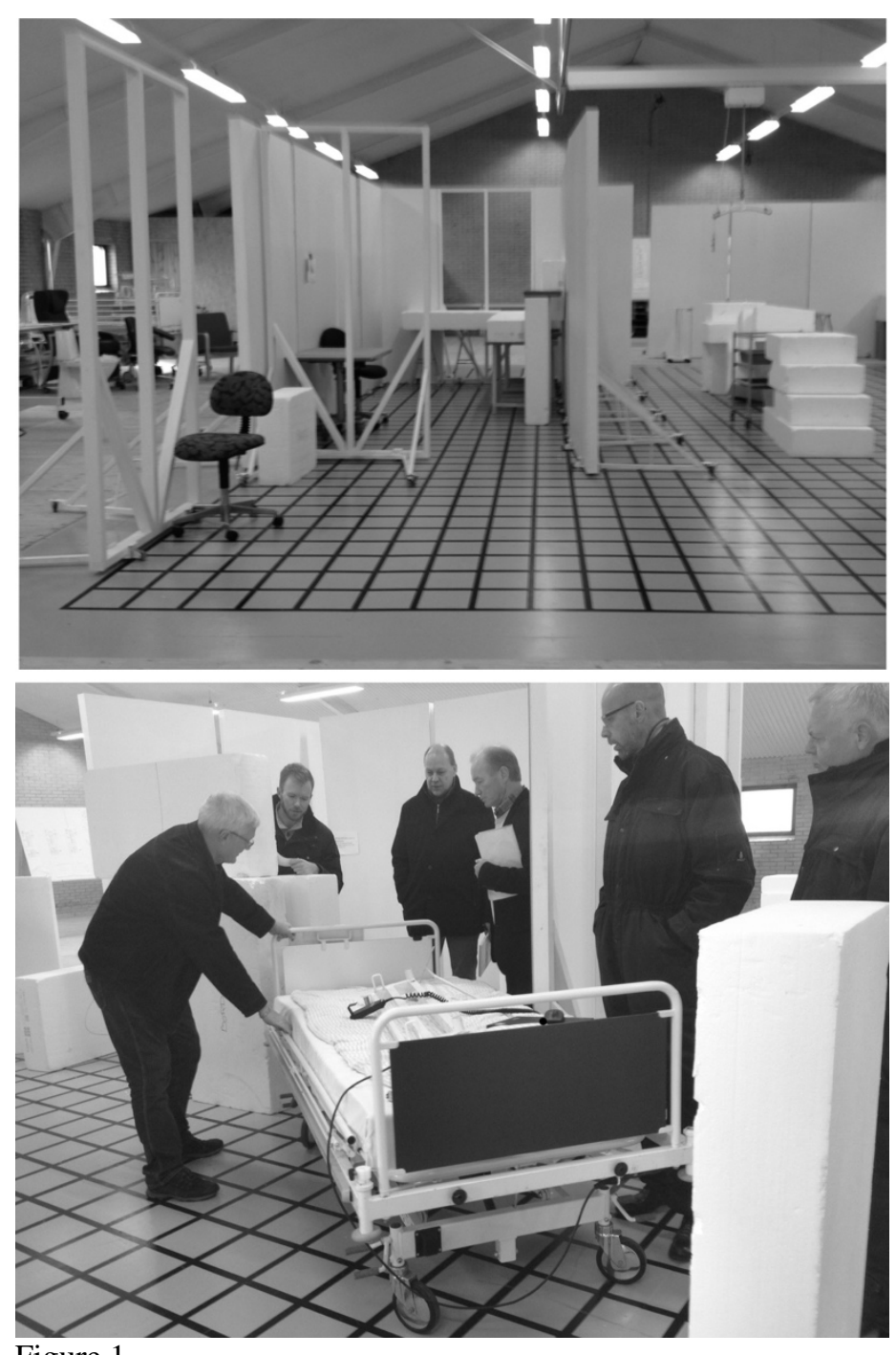

Figure 1 


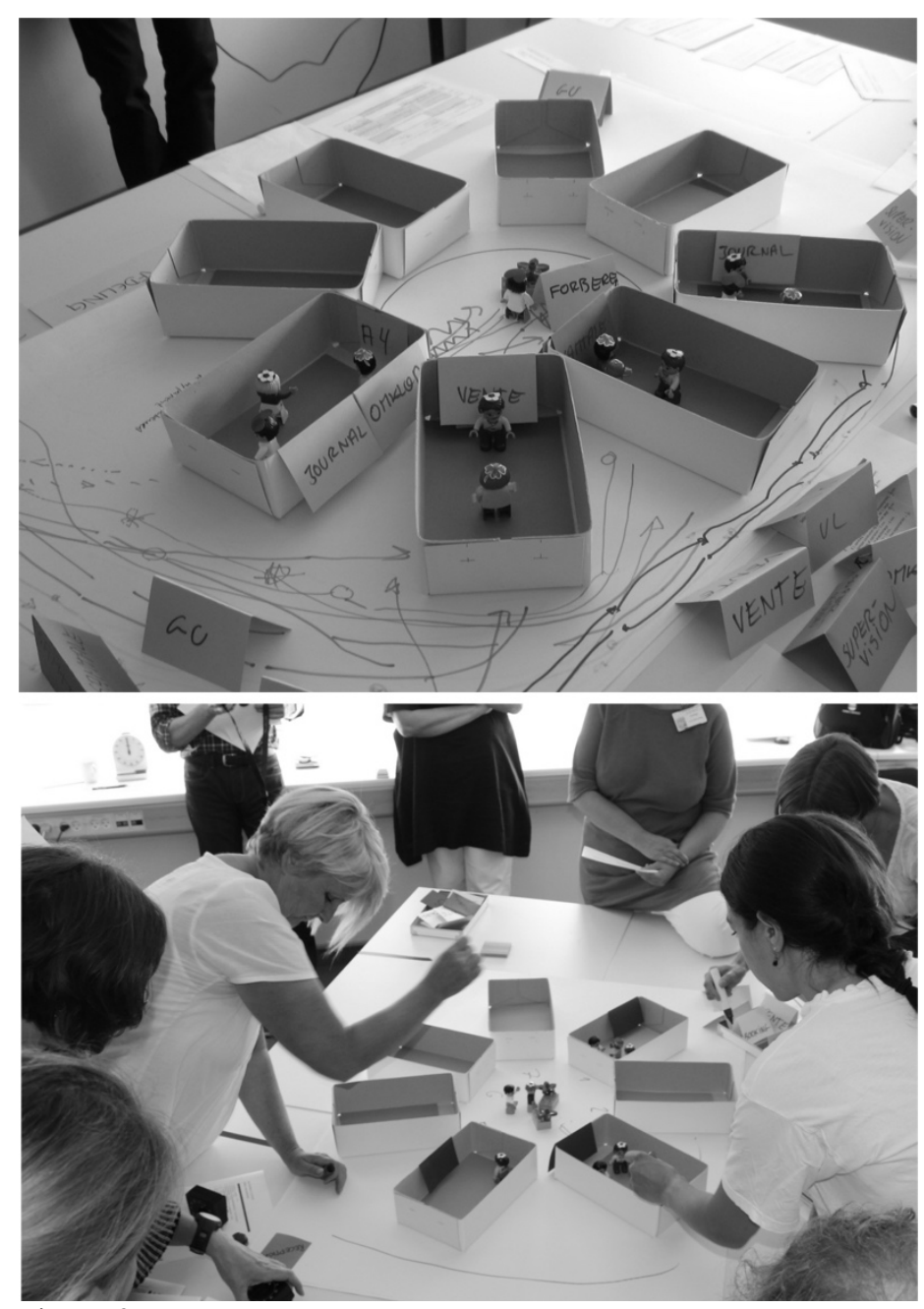

Figure 2 


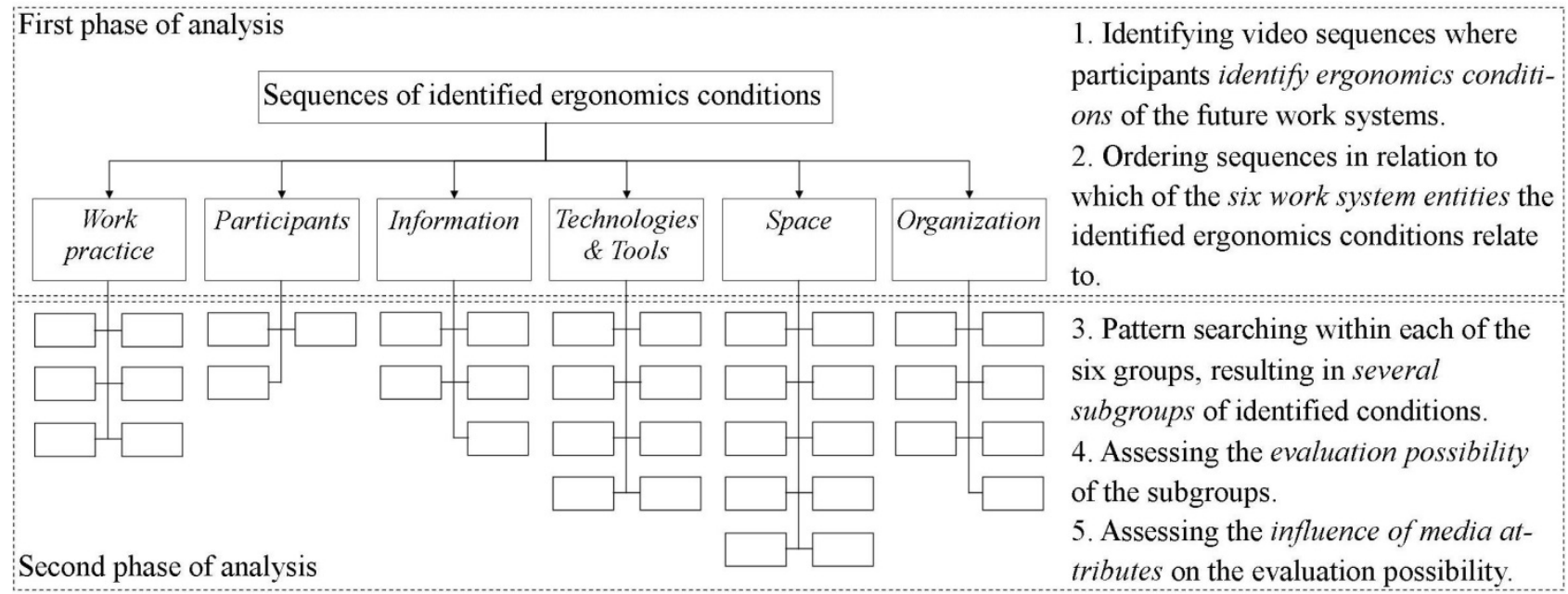

Figure 3

Percentage of identified ergonomics conditions

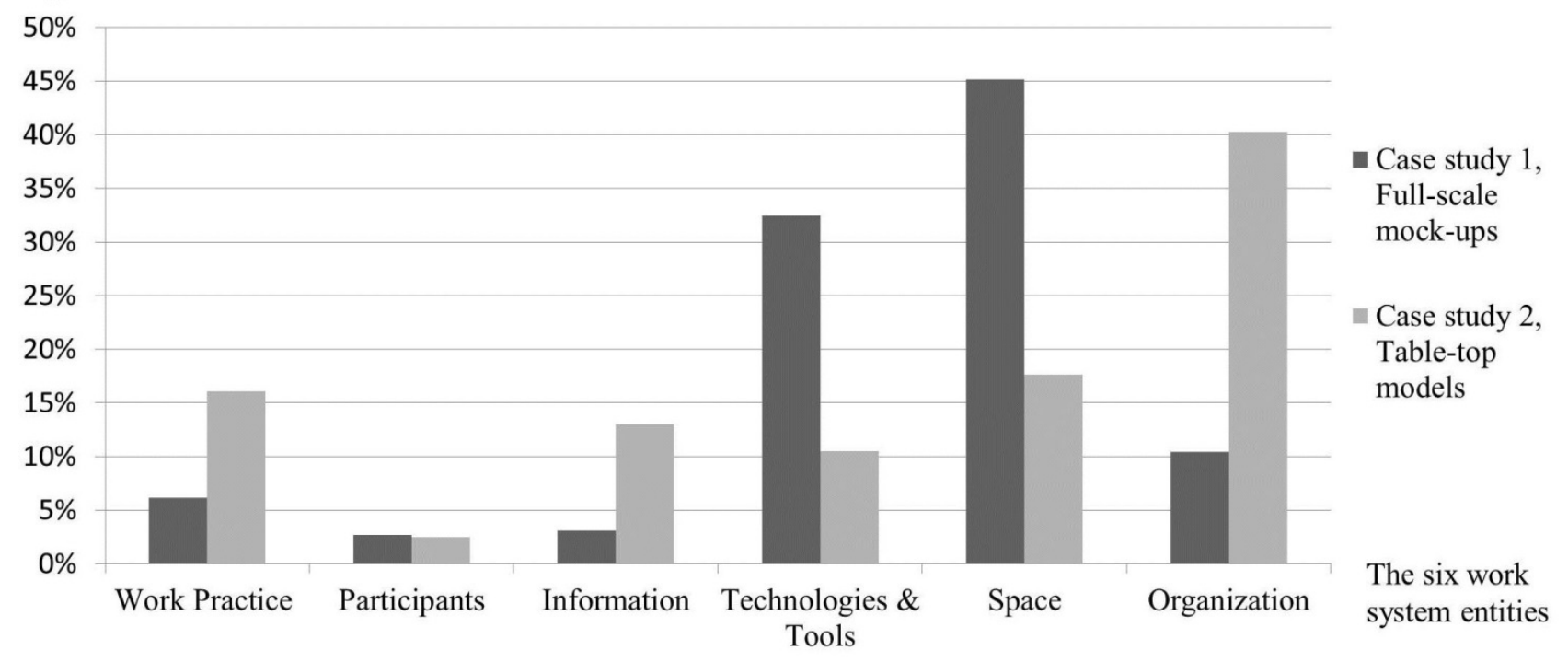

Figure 4 


\begin{tabular}{|c|c|c|c|c|}
\hline & Sim event 1 & Sim event 2 & Sim event 3 & Sim event 4 \\
\hline Duration & 1 hour & 1 hour & 1,5 hour & 2 hours \\
\hline $\begin{array}{l}\text { Simulation } \\
\text { medium }\end{array}$ & $\begin{array}{l}\text { Full-scale mock-up of } \\
\text { standard reception in } \\
\text { bed ward. }\end{array}$ & $\begin{array}{l}\text { Full-scale mock-up of } \\
\text { standard examination } \\
\text { room in outpatient } \\
\text { department. }\end{array}$ & $\begin{array}{l}\text { Full-scale mock-up of } \\
\text { depot in standard bed } \\
\text { ward. }\end{array}$ & $\begin{array}{l}\text { Full-scale mock-up of } \\
\text { standard bed } \\
\text { paternoster lift and } \\
\text { hallway. }\end{array}$ \\
\hline Participants & $\begin{array}{l}\text { - Three medical } \\
\text { secretaries. } \\
\text { - One executive } \\
\text { medical secretary. } \\
\text { - Three executive } \\
\text { nurses from three } \\
\text { areas of } \\
\text { specialization. } \\
\text { - One staff member } \\
\text { from hospital } \\
\text { management group. } \\
\text { - One staff member } \\
\text { from project division } \\
\text { focusing on space } \\
\text { documentation. } \\
\text { - Two IT consultants. } \\
\text { - Two center } \\
\text { facilitators. }\end{array}$ & $\begin{array}{l}\text { - Three medical } \\
\text { secretaries. } \\
\text { - One executive } \\
\text { medical secretary. } \\
\text { - Three executive } \\
\text { nurses from three } \\
\text { areas of } \\
\text { specialization. } \\
\text { - One staff member } \\
\text { from hospital } \\
\text { management group. } \\
\text { - One staff member } \\
\text { from project division } \\
\text { focusing on space } \\
\text { documentation. } \\
\text { - Two IT consultants. } \\
\text { - Two center } \\
\text { facilitators. }\end{array}$ & $\begin{array}{l}\text { - Three executive } \\
\text { nurses from three } \\
\text { areas of } \\
\text { specialization. } \\
\text { - One staff member } \\
\text { from project division } \\
\text { focusing on logistics. } \\
\text { - One staff member } \\
\text { from project division } \\
\text { focusing on space } \\
\text { documentation. } \\
\text { - Two center } \\
\text { facilitators. }\end{array}$ & $\begin{array}{l}\text { - One hospital orderly } \\
\text { - One employee from } \\
\text { the hospital technical } \\
\text { department. } \\
\text { - Two staff members } \\
\text { from project division } \\
\text { focusing on logistics. } \\
\text { - One consulting } \\
\text { architect. } \\
\text { - One project } \\
\text { engineer. } \\
\text { - Two technical } \\
\text { consultants. } \\
\text { - Two center } \\
\text { facilitators. }\end{array}$ \\
\hline Purpose & $\begin{array}{l}\text { Exploring work tasks } \\
\text { of logistical } \\
\text { coordination within } \\
\text { the layout of the } \\
\text { reception and back- } \\
\text { office area. }\end{array}$ & $\begin{array}{l}\text { Exploring work tasks } \\
\text { of patient } \\
\text { examination within } \\
\text { the layout of the } \\
\text { examination room. }\end{array}$ & $\begin{array}{l}\text { Exploring work tasks } \\
\text { of aids handling and } \\
\text { storage within the } \\
\text { layout of the depot. }\end{array}$ & $\begin{array}{l}\text { Exploring work tasks } \\
\text { of bed handling } \\
\text { within the layout of } \\
\text { the bed paternoster } \\
\text { and hallways. }\end{array}$ \\
\hline
\end{tabular}

Table 1: Key characteristics of the four simulation events of the first case study. (Two column table) 


\begin{tabular}{|c|c|c|c|c|}
\hline & Sim event 1 & Sim event 2 & Sim event 3 & Sim event 4 \\
\hline Duration & 1,5 hour & 1,5 hour & 2 hours & 1,5 hour \\
\hline $\begin{array}{l}\text { Simulation } \\
\text { medium }\end{array}$ & $\begin{array}{l}\text { Table-top model of } \\
\text { separate examination } \\
\text { and conversation } \\
\text { rooms. }\end{array}$ & $\begin{array}{l}\text { Table-top model of } \\
\text { one examination room } \\
\text { per two conversation } \\
\text { rooms. }\end{array}$ & $\begin{array}{l}\text { Table-top model of } \\
\text { multifunctional } \\
\text { examination rooms } \\
\text { and staff area. }\end{array}$ & $\begin{array}{l}\text { Table-top model of } \\
\text { multifunctional } \\
\text { examination rooms } \\
\text { and staff area. }\end{array}$ \\
\hline Participants & $\begin{array}{l}\text { - One chief surgeon } \\
\text { related to the } \\
\text { outpatient } \\
\text { department. } \\
\text { - One outpatient } \\
\text { department nurse. } \\
\text { - One medical } \\
\text { secretary. } \\
\text { - One OHS consultant } \\
\text { from industry. } \\
\text { - Two simulation } \\
\text { consultants. } \\
\text { - Three researchers in } \\
\text { performance and } \\
\text { ergonomics. }\end{array}$ & $\begin{array}{l}\text { - One chief surgeon } \\
\text { related to the } \\
\text { outpatient } \\
\text { department. } \\
\text { - One outpatient } \\
\text { department nurse. } \\
\text { - One medical } \\
\text { secretary. } \\
\text { - One OHS consultant } \\
\text { from industry. } \\
\text { - Two simulation } \\
\text { consultants. } \\
\text { - Three researchers in } \\
\text { performance and } \\
\text { ergonomics. }\end{array}$ & $\begin{array}{l}\text { - One chief surgeon } \\
\text { related to the } \\
\text { outpatient } \\
\text { department. } \\
\text { - One outpatient } \\
\text { department nurse. } \\
\text { - One medical } \\
\text { secretary. } \\
\text { - One OHS consultant } \\
\text { from industry. } \\
\text { - Two simulation } \\
\text { consultants. } \\
\text { - Three researchers in } \\
\text { performance and } \\
\text { ergonomics. }\end{array}$ & $\begin{array}{l}\text { - One chief surgeon } \\
\text { related to the } \\
\text { outpatient } \\
\text { department. } \\
\text { - Three outpatient } \\
\text { department nurses. } \\
\text { - Two outpatient } \\
\text { department } \\
\text { physicians. } \\
\text { - One OHS consultant } \\
\text { from industry. } \\
\text { - One construction } \\
\text { consultant from } \\
\text { industry. } \\
\text { - One simulation } \\
\text { consultants. } \\
\text { - Three researchers in } \\
\text { performance and } \\
\text { ergonomics. }\end{array}$ \\
\hline Purpose & $\begin{array}{l}\text { Exploring work tasks } \\
\text { of patient examination } \\
\text { within the classic } \\
\text { layout of the } \\
\text { outpatient } \\
\text { department. }\end{array}$ & $\begin{array}{l}\text { Exploring work tasks } \\
\text { of patient examination } \\
\text { within layout based on } \\
\text { a shared examination } \\
\text { room per two } \\
\text { conversation rooms. }\end{array}$ & $\begin{array}{l}\text { Exploring work tasks } \\
\text { of patient examination } \\
\text { within layout based on } \\
\text { multifunctional } \\
\text { examination rooms. }\end{array}$ & $\begin{array}{l}\text { Exploring work tasks } \\
\text { of patient examination } \\
\text { within layout based on } \\
\text { multifunctional } \\
\text { examination rooms. }\end{array}$ \\
\hline
\end{tabular}

Table 2: Key characteristics of the four simulation events of the second case study. (Two column table) 


\begin{tabular}{|c|c|c|c|c|}
\hline \multirow[t]{2}{*}{ Media } & \multicolumn{2}{|c|}{ Fidelity } & \multicolumn{2}{|c|}{ Affordance } \\
\hline & High & Low & High & Low \\
\hline $\begin{array}{l}\text { Full-scale } \\
\text { mock-ups }\end{array}$ & $\begin{array}{l}\text { Room layout and } \\
\text { specific dimensions of } \\
\text { rooms. Positions and } \\
\text { dimensions of } \\
\text { technologies and } \\
\text { interior. }\end{array}$ & $\begin{array}{l}\text { Sole manifestation of } \\
\text { single rooms } \\
\text { excluding } \\
\text { representation of } \\
\text { external functions and } \\
\text { coordination. }\end{array}$ & $\begin{array}{l}\text { Easy configuration of } \\
\text { the movable walls by } \\
\text { the participants. } \\
\text { Thereby, supporting } \\
\text { redesign of the room } \\
\text { dimension and shape } \\
\text { in full-scale. }\end{array}$ & $\begin{array}{l}\text { No configuration of } \\
\text { more than a few } \\
\text { rooms, resulting in } \\
\text { low possibility for } \\
\text { testing collaboration } \\
\text { and coordination } \\
\text { between several } \\
\text { rooms. }\end{array}$ \\
\hline $\begin{array}{l}\text { Table-top } \\
\text { models }\end{array}$ & $\begin{array}{l}\text { Detailed manifestation } \\
\text { of the overall building } \\
\text { layout, internal } \\
\text { relations and } \\
\text { coordination. }\end{array}$ & $\begin{array}{l}\text { Black-boxing each of } \\
\text { the rooms of the } \\
\text { future work system } \\
\text { into shoeboxes, not } \\
\text { manifesting layout } \\
\text { and the technologies } \\
\text { within. }\end{array}$ & $\begin{array}{l}\text { Easy room } \\
\text { configuration, giving a } \\
\text { helicopter view of the } \\
\text { overall building } \\
\text { layout. Thereby, } \\
\text { providing overview of } \\
\text { collaboration and } \\
\text { communication } \\
\text { between different } \\
\text { professions. }\end{array}$ & $\begin{array}{l}\text { No changing of room } \\
\text { dimensions and } \\
\text { shape, the shoeboxes } \\
\text { had only one } \\
\text { geometry, } \\
\text { representing the } \\
\text { future rooms. }\end{array}$ \\
\hline
\end{tabular}

Table 3: The fidelity and affordance of the two simulation media. (Two column table) 


\begin{tabular}{|c|c|c|c|c|}
\hline & $\begin{array}{l}\text { Subgroups with high possibility for } \\
\text { evaluation }\end{array}$ & $\begin{array}{l}\text { Media attributes } \\
\text { related to high } \\
\text { evaluation possibility }\end{array}$ & $\begin{array}{l}\text { Subgroups with low possibility for } \\
\text { evaluation }\end{array}$ & $\begin{array}{l}\text { Media attributes } \\
\text { related to low } \\
\text { evaluation possibility }\end{array}$ \\
\hline \multicolumn{5}{|c|}{ Full-scale mock-ups } \\
\hline 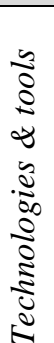 & $\begin{array}{l}\text {-Execution of work is influenced by } \\
\text { placement of technology within the } \\
\text { room. } \\
\text { - Execution of work is influenced by the } \\
\text { dimensions of the tools and } \\
\text { technologies. } \\
\text { - Work posture is influenced by the } \\
\text { tools and technologies. }\end{array}$ & \begin{tabular}{|l} 
High fidelity of \\
dimensions of \\
technologies and tools. \\
Affording bodily \\
operation of \\
technologies and tools.
\end{tabular} & $\begin{array}{l}\text {-Efficiency of work is influenced by } \\
\text { the number of tools per room. } \\
\text {-Efficiency of work is influenced by } \\
\text { the types of tools within the room. } \\
\text { - Efficiency of work is influenced by } \\
\text { supporting tools for logistics and } \\
\text { distribution of labor. }\end{array}$ & $\begin{array}{l}\text { Low fidelity of technical } \\
\text { systems and specific } \\
\text { specialized instruments. } \\
\text { Do not afford } \\
\text { exploration of relations } \\
\text { between several rooms. }\end{array}$ \\
\hline 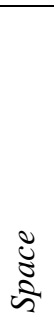 & $\begin{array}{l}\text { - Work practice is influenced by room } \\
\text { shape. } \\
\text { - Work practice is influenced by } \\
\text { dimensions of interior. } \\
\text { - Work posture and practice is } \\
\text { influenced by room layout. } \\
\text { - Area utilization is influenced by } \\
\text { arrangement of interior. }\end{array}$ & \begin{tabular}{|l|} 
High fidelity of room \\
dimensions and layout. \\
Affording bodily \\
exploration and \\
configuration of interior \\
and room shape.
\end{tabular} & $\begin{array}{l}\text { - Quality of work is influenced by noise } \\
\text { level. } \\
\text { - Psychosocial conditions are } \\
\text { influenced by the room layout. } \\
\text { - Physical conditions are influenced by } \\
\text { light inflow. } \\
\text { - Room layout and functions are } \\
\text { influenced by external rooms' shapes } \\
\text { and functions. }\end{array}$ & $\begin{array}{l}\text { Low fidelity of material } \\
\text { properties and light } \\
\text { inflow. } \\
\text { Do not afford } \\
\text { exploration of a several } \\
\text { rooms e.g. in a } \\
\text { department. }\end{array}$ \\
\hline 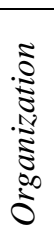 & - & - & $\begin{array}{l}\text { - Division of labor influences the } \\
\text { rooms’ layout. } \\
\text { - Organization of work tasks for } \\
\text { obtaining efficiency. }\end{array}$ & $\begin{array}{l}\text { Low fidelity of the } \\
\text { overall department } \\
\text { layout. } \\
\text { Do not afford } \\
\text { exploration of relations } \\
\text { between several rooms. }\end{array}$ \\
\hline \multicolumn{5}{|c|}{ Table-top models } \\
\hline 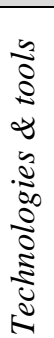 & $\begin{array}{l}\text { - Technologies for managing the overall } \\
\text { patient flow. } \\
\text {-Existing system problems are } \\
\text { decreasing the efficiency. }\end{array}$ & \begin{tabular}{|l|} 
High fidelity of the \\
flows of patients and \\
staff. \\
Affording test and \\
overview of several \\
patient trajectories at the \\
same time.
\end{tabular} & $\begin{array}{l}\text { - The sufficient types of tools within the } \\
\text { rooms influence the efficiency. } \\
\text { - Technology functions supporting key } \\
\text { work. } \\
\text { - Team formation supporting tools for } \\
\text { effective collaboration. }\end{array}$ & $\begin{array}{l}\text { Low fidelity of the } \\
\text { content of specific } \\
\text { rooms. } \\
\text { Do not afford test of the } \\
\text { specific tools within the } \\
\text { rooms. }\end{array}$ \\
\hline $\begin{array}{l}\tilde{\Xi} \\
\vdots \\
\text { के }\end{array}$ & $\begin{array}{l}\text { - The building layout influences the } \\
\text { organization. } \\
\text { - Decreasing walking distances for the } \\
\text { workers. } \\
\text { - Placement of rooms in relation to each } \\
\text { other. }\end{array}$ & $\begin{array}{l}\text { High fidelity of the } \\
\text { overall department } \\
\text { layout. } \\
\text { Affording a helicopter } \\
\text { view of the department } \\
\text { and activities taking } \\
\text { place. }\end{array}$ & $\begin{array}{l}\text { - Interior layout supports work tasks. } \\
\text { - Building shape influences the room } \\
\text { shapes. } \\
\text { - Numbers of each room type for } \\
\text { covering the work tasks taking place. }\end{array}$ & $\begin{array}{l}\text { Low fidelity of the } \\
\text { layout of individual } \\
\text { rooms. } \\
\text { Do not afford } \\
\text { exploration of single } \\
\text { rooms, due to rooms } \\
\text { being 'black boxed' into } \\
\text { cardboard boxes. }\end{array}$ \\
\hline 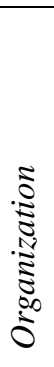 & $\begin{array}{l}\text { - Psychosocial conditions are } \\
\text { influenced by work organization. } \\
\text { - Organization of work is influenced by } \\
\text { building layout. } \\
\text { - Team formation is influenced by the } \\
\text { organization and building layout. } \\
\text { - Division of labor is a part of the work } \\
\text { organization. } \\
\text { - Work organization is influenced by } \\
\text { effective coordination. }\end{array}$ & \begin{tabular}{|l|} 
High fidelity of the \\
overall building layout \\
and functions. \\
Affording a helicopter \\
view of the relations and \\
coordination between \\
functions. Easy \\
configuration of rooms.
\end{tabular} & $\begin{array}{l}\text {-Efficient organization is influenced by } \\
\text { relation to external functions. } \\
\text { - Efficiency of work is influenced by } \\
\text { the organization of activities in } \\
\text { advance. }\end{array}$ & $\begin{array}{l}\text { Low fidelity of relations } \\
\text { to external functions } \\
\text { outside the department. } \\
\text { Do not afford } \\
\text { exploration of tasks not } \\
\text { predefined, such as the } \\
\text { social relations in } \\
\text { ongoing team formation. }\end{array}$ \\
\hline
\end{tabular}

Table 4: The evaluation possibility of the subgroups of the three dominating work system entities, and the influence of the media attributes. (Two column table) 


\begin{tabular}{|c|c|c|}
\hline & Full-scale mock-ups & Table-top models \\
\hline 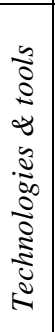 & $\begin{array}{l}\text { - Movement of equipment/components (Hignett et al., 2010; } \\
\text { Villeneuve et al., 2007) } \\
\text { - Dimensions of equipment and furnishing (Hignett et al., 2010; } \\
\text { Steinfeld, 2004) } \\
\text { - Work posture (Hallbeck et al., 2010) } \\
\text { - Operation task time (Paquet and Lin, 2003) } \\
\text { - Usability of tools and products (Paquet and Lin, 2003; Watkins } \\
\text { et al., 2008) } \\
\text { - Furnishing and equipment (Peavey et al., 2012) }\end{array}$ & -Communication technology (Ruohomäki, 2003) \\
\hline $\begin{array}{l}\tilde{g} \\
\tilde{\Xi} \\
\omega^{2}\end{array}$ & $\begin{array}{l}\text { - Depths, heights and positions (Bligård et al., 2014; Hignett et } \\
\text { al., 2010; Peavey et al., 2012; Steinfeld, 2004; Watkins et al., } \\
\text { 2008) } \\
\text { - Usability of workstations (Paquet and Lin, 2003) } \\
\text { - Physical requirements (Paquet and Lin, 2003) } \\
\text { - Room dimensions and layout (Peavey et al., 2012; Villeneuve et } \\
\text { al., 2007) } \\
\text { - Materials (Peavey et al., 2012) } \\
\text { - Interior designs (Persson et al., 2014) } \\
\text { - Space sizes and planning (Steinfeld, 2004; Watkins et al., 2008) }\end{array}$ & $\begin{array}{l}\text { - Plant layout (Daniellou et al., 2014; Riis, 1996) } \\
\text { - Depths and relative heights (Bligård et al., 2014) } \\
\text { - Spatial provision required (Ewenstein and Whyte, 2007) }\end{array}$ \\
\hline 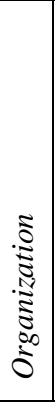 & $\begin{array}{l}\text { - Distraction in work (Peavey et al., 2012) } \\
\text { - Cognitive workload (Paquet and Lin, 2003) }\end{array}$ & $\begin{array}{l}\text { - Work activities (Ruohomäki, 2003) } \\
\text { - Human interaction (Ruohomäki, 2003) } \\
\text { - Division of work and production schedule (Forssén-Nyberg and } \\
\text { Makamäki, 1998; Ruohomäki, 2003; Savolainen, 1997) } \\
\text {-Communication and cooperation (Forssén-Nyberg and } \\
\text { Makamäki, 1998; Riis, 1996; Ruohomäki, 2003) } \\
\text { - Unnecessary repetition (Ruohomäki, 2003) } \\
\text { - Team reactivity (Daniellou et al., 2014) } \\
\text { - Resources that are allocated (Daniellou et al., 2014) } \\
\text { - Interdependence between departments (Forssén-Nyberg and } \\
\text { Makamäki, 1998; Riis, 1996) }\end{array}$ \\
\hline
\end{tabular}

Table 5: Identified ergonomics conditions of existing studies of full-scale mock-ups and table-top based simulation.

(Two column table) 


\begin{tabular}{|c|c|c|c|c|c|c|c|}
\hline \multirow[t]{2}{*}{$\begin{array}{l}\text { Work system } \\
\text { entities }\end{array}$} & \multirow{2}{*}{$\begin{array}{l}\text { Subcategories of identified ergonomics conditions: } \\
\text { Conditions influencing the well-being and performance of the } \\
\text { future work system. }\end{array}$} & \multicolumn{5}{|c|}{$\begin{array}{c}\text { Numbers of transcribed } \\
\text { sequences }\end{array}$} & \multirow{2}{*}{$\begin{array}{l}\text { Possibility for } \\
\text { evaluation by } \\
\text { the simulation } \\
\text { participants }\end{array}$} \\
\hline & & $\begin{array}{c}\text { Case } \\
1\end{array}$ & $\begin{array}{c}\text { Case } \\
2\end{array}$ & Case & $\begin{array}{c}\text { Case } \\
4\end{array}$ & Total & \\
\hline \multicolumn{8}{|c|}{ Case study 1: Full-scale mock-ups } \\
\hline \multirow[t]{3}{*}{ Work Practice } & - The work practice today & 2 & 0 & 0 & 2 & \multirow[t]{3}{*}{$16(6 \%)$} & Low \\
\hline & - The room restricts the work practice & 0 & 0 & 0 & 2 & & Low \\
\hline & - The room supports efficient work practices & 0 & 1 & 6 & 3 & & High \\
\hline \multirow[t]{2}{*}{ Participants } & - Worker which are not central participants influence as well & 0 & 0 & 2 & 3 & \multirow{2}{*}{$\begin{array}{c}7 \\
(3 \%)\end{array}$} & Low \\
\hline & - The key participants are the main users & 1 & 0 & 0 & 1 & & High \\
\hline \multirow[t]{2}{*}{ Information } & - Discrete information sharing is required & 4 & 0 & 0 & 0 & \multirow{2}{*}{$\begin{array}{c}8 \\
(3 \%)\end{array}$} & Low \\
\hline & $\begin{array}{l}\text { - The right information has to go to the right people for } \\
\text { increased efficiency }\end{array}$ & 3 & 0 & 1 & 0 & & Low \\
\hline \multirow[t]{6}{*}{$\begin{array}{l}\text { Technologies } \\
\text { \& Tools }\end{array}$} & $\begin{array}{l}\text {-Efficiency of work is influenced by the number of tools per } \\
\text { room }\end{array}$ & 0 & 5 & 4 & 4 & \multirow[t]{6}{*}{$\begin{array}{c}84 \\
(32 \%)\end{array}$} & Low \\
\hline & \begin{tabular}{|l} 
- Execution of work is influenced by placement of technology \\
within the room
\end{tabular} & 2 & 3 & 5 & 4 & & High \\
\hline & $\begin{array}{l}\text { - Execution of work is influenced by the dimensions of the } \\
\text { tools and technologies }\end{array}$ & 0 & 0 & 2 & 6 & & High \\
\hline & $\begin{array}{l}\text { - Efficiency of work is influenced by the types of tools within } \\
\text { the room }\end{array}$ & 1 & 11 & 7 & 0 & & Low \\
\hline & - Work posture is influenced by the tools and technologies & 12 & 1 & 6 & 5 & & High \\
\hline & $\begin{array}{l}\text {-Efficiency of work is influenced by supporting tools for } \\
\text { logistics and distribution of labor }\end{array}$ & 4 & 1 & 1 & 0 & & Low \\
\hline \multirow[t]{8}{*}{ Space } & -Quality of work is influenced by noise level & 3 & 0 & 0 & 3 & \multirow{8}{*}{$\begin{array}{c}117 \\
(45 \%)\end{array}$} & Low \\
\hline & \begin{tabular}{|l}
-Psychosocial conditions are influenced by the room layout \\
\end{tabular} & 4 & 0 & 0 & 0 & & Low \\
\hline & -Work practice is influenced by room shape & 6 & 1 & 1 & 16 & & High \\
\hline & -Physical conditions are influenced by light inflow & 2 & 1 & 2 & 0 & & Low \\
\hline & -Work practice is influenced by dimensions of interior & 3 & 0 & 8 & 1 & & High \\
\hline & $\begin{array}{l}\text { - Room layout and functions are influenced by external } \\
\text { rooms' shapes and functions }\end{array}$ & 2 & 2 & 0 & 0 & & Low \\
\hline & - Work posture and practice is influenced by room layout & 2 & 2 & 12 & 10 & & High \\
\hline & - Area utilization is influenced by arrangement of interior & 7 & 11 & 18 & 0 & & High \\
\hline \multirow[t]{2}{*}{ Organization } & -Division of labor influences the rooms' layout & 13 & 0 & 0 & 3 & \multirow{2}{*}{$\begin{array}{c}27 \\
(10 \%)\end{array}$} & Low \\
\hline & - Organization of work tasks for obtaining efficiency & 0 & 6 & 1 & 4 & & Low \\
\hline Total & & & & & & $\begin{array}{c}259 \\
(100 \%) \\
\end{array}$ & \\
\hline \multicolumn{8}{|c|}{ Case study 2: Table-top models } \\
\hline \multirow[t]{6}{*}{ Work practice } & - Utilization of spare time for key work practices & 2 & 3 & 5 & 1 & \multirow{6}{*}{$\begin{array}{c}52 \\
(16 \%)\end{array}$} & $\overline{\text { Low }}$ \\
\hline & -Work practice frequency influences the work system & 2 & 1 & 0 & 0 & & Low \\
\hline & \begin{tabular}{|l} 
- The work practice today \\
\end{tabular} & 1 & 0 & 2 & 4 & & Low \\
\hline & - The time needed for work tasks & 9 & 2 & 2 & 1 & & Low \\
\hline & - People have personal preferences to work tasks & 2 & 1 & 0 & 6 & & Low \\
\hline & -Disturbances of work practices is decreasing the efficiency & 1 & 2 & 5 & 0 & & High \\
\hline \multirow[t]{3}{*}{ Participants } & $\begin{array}{l}\text { - Number of special participants needed for the optimal } \\
\text { quality of work }\end{array}$ & 1 & 0 & 1 & 0 & \multirow[t]{3}{*}{$\begin{array}{c}8 \\
(2 \%)\end{array}$} & Low \\
\hline & -Experience of the participants needed in certain situations & 1 & 1 & 0 & 1 & & Low \\
\hline & - Different participants have different authority & 0 & 0 & 2 & 1 & & High \\
\hline \multirow[t]{3}{*}{ Information } & - Room layout support of informal communication & 0 & 1 & 5 & 1 & 42 & High \\
\hline & - The basic information needed in the work & 0 & 7 & 3 & 3 & $(13 \%)$ & Low \\
\hline & - Information needed in unintended situations & 8 & 0 & 5 & 9 & & High \\
\hline $\begin{array}{l}\text { Technologies } \\
\text { \& Tools }\end{array}$ & $\begin{array}{l}\text { - The sufficient types of tools within the rooms influence the } \\
\text { efficiency }\end{array}$ & 1 & 3 & 3 & 1 & $\begin{array}{c}34 \\
(11 \%)\end{array}$ & Low \\
\hline & - Technologies for managing the overall patient flow & 0 & 3 & 0 & 1 & & High \\
\hline & - Technology functions supporting key work & 0 & 1 & 1 & 2 & & Low \\
\hline & -Existing system problems are decreasing the efficiency & 3 & 0 & 1 & 1 & & High \\
\hline & - Team formation supporting tools for effective collaboration & 6 & 2 & 1 & 4 & & Low \\
\hline
\end{tabular}




\begin{tabular}{|c|c|c|c|c|c|c|c|}
\hline \multirow[t]{6}{*}{ Space } & - The building layout influences the organization & 6 & 4 & 6 & 2 & \multirow{6}{*}{$\begin{array}{c}57 \\
(18 \%)\end{array}$} & High \\
\hline & -Decreasing walking distances for the workers & 2 & 3 & 2 & 2 & & High \\
\hline & -Interior layout supports work tasks & 2 & 3 & 4 & 0 & & Low \\
\hline & -Building shape influences the room shapes & 0 & 1 & 2 & 0 & & Low \\
\hline & -Placement of rooms in relation to each other & 5 & 1 & 3 & 1 & & High \\
\hline & $\begin{array}{l}\text { - Numbers of each room type for covering the work tasks } \\
\text { taking place }\end{array}$ & 2 & 2 & 4 & 0 & & Low \\
\hline \multirow[t]{7}{*}{ Organization } & -Psychosocial conditions are influenced by work organization & 0 & 5 & 10 & 5 & \multirow{7}{*}{$\begin{array}{c}130 \\
(40 \%)\end{array}$} & High \\
\hline & $\begin{array}{l}\text {-Efficient organization is influenced by relation to external } \\
\text { functions }\end{array}$ & 4 & 1 & 0 & 0 & & Low \\
\hline & -Organization of work is influenced by building layout & 3 & 16 & 11 & 4 & & High \\
\hline & $\begin{array}{l}\text { - Team formation is influenced by the organization and } \\
\text { building layout. }\end{array}$ & 8 & 7 & 6 & 0 & & High \\
\hline & -Division of labor is a part of the work organization & 9 & 3 & 8 & 9 & & High \\
\hline & $\begin{array}{l}\text {-Efficiency of work is influenced by the organization of } \\
\text { activities in advance }\end{array}$ & 2 & 3 & 2 & 1 & & Low \\
\hline & - Work organization is influenced by effective coordination & 5 & 4 & 1 & 3 & & High \\
\hline Total & & & & & & $\begin{array}{c}323 \\
(100 \%)\end{array}$ & \\
\hline
\end{tabular}

Table A.1: Results from the analysis of the two multiple case studies. (Two column table) 